\title{
Nutritional quality of foods and non- alcoholic beverages advertised on Mexican television according to three nutrient profile models
}

Sofía Rincón-Gallardo Patiño ${ }^{1}$, Lizbeth Tolentino-Mayo ${ }^{1 *}$, Eric Alejandro Flores Monterrubio ${ }^{1}$, Jennifer L Harris², Stefanie Vandevijvere ${ }^{3}$, Juan A Rivera ${ }^{1}$ and Simón Barquera ${ }^{1}$

\begin{abstract}
Background: Evidence supports that television food advertisements influence children's food preferences and their consumption. However, few studies have examined the extent and nature of food marketing to children in low and middle income countries. This study aims to assess the nutritional quality of foods and beverages advertised on Mexican TV, applying the Mexican, World Health Organization (WHO) European and United Kingdom (UKNPM) nutrient profile models, before the Mexican regulation on food marketing came into effect.

Methods: We recorded $600 \mathrm{~h}$ on the four national public and free TV channels with the highest national ratings, from December 2012 to April 2013. Recordings were done for 40 randomly selected (week, weekend, school and vacation) days, from $7 \mathrm{am}$ to $10 \mathrm{pm}$. Nutritional information per $100 \mathrm{~g} / \mathrm{ml}$ of product was obtained from the product labels or company websites.

Results: A total of 2,544 food and non-alcoholic beverage advertisements were broadcast, for 275 different products. On average, the foods advertised during cartoon programming had the highest energy (367 kcal) and sugar (30.0 g) content, while foods advertised during sport programming had the highest amount of total fat ( 9 . $5 \mathrm{~g}$ ) and sodium $(412 \mathrm{mg}$ ) content. More than $60 \%$ of the foods advertised did not meet any nutritional quality standards. $64.3 \%$ of the products did not comply with the Mexican nutritional standards, as compared with 83 . $1 \%$ and $78.7 \%$ with WHO Europe and UKNPM standards, respectively. The food groups most frequently advertised were beverages (24.6\%), followed by chocolate and confectionery sugar (19.7\%), cakes, sweet biscuits and pastries (12.0\%), savory snacks (9.3\%), breakfast cereals (7.1\%), ready-made food (6.4\%) and dairy products (6.0 \%).

Conclusion: The majority of foods and beverages advertised on Mexican TV do not comply with any nutritional quality standards, and thus should not be marketed to children. The nutritional quality standards applied by the Mexican regulation are much weaker than those applied by the WHO Europe and United Kingdom. The Mexican government should improve the nutrition standards in its new regulation, especially the sugar cut off points.
\end{abstract}

Keywords: Television, Advertising, Food and beverages, Nutritional content, Mexico, Nutrient profile models

\footnotetext{
* Correspondence: mltolentino@insp.mx

${ }^{1}$ Centro de Investigación en Nutrición y Salud, Instituto Nacional de Salud

Pública, Av. Universidad No. 655, CP 62100 Cuernavaca, Morelos, México

Full list of author information is available at the end of the article
} 


\section{Background}

Over the past decades the prevalence of childhood obesity has risen internationally [1] and has been recognized as a global public health problem [2]. Child obesity rates have increased in Mexico as well. The National Health and Nutrition Survey 2012 (ENSANUT, for its acronym in spanish) [3] found that the prevalence of overweight and obesity among children under 5 years increased from $26.6 \%$ to $33.6 \%$ between 1988 and $2012(0.3$ percentage point per year), and from $28.2 \%$ to $36.9 \%$ for children 5-11 years between 1999 and 2012 (0.7 percentage point per year). Childhood obesity is linked to cardiovascular risk factors, type 2 diabetes, dental caries and chronic diseases later in life $[4,5]$. This problem has been attributed to numerous causes, including a sedentary lifestyle, an unhealthy diet, socioeconomic status, the physical environment, and integrated food marketing through multimedia $[6,7]$.

Evidence supports that television (TV) viewing is associated with obesity among children, because it is a major sedentary activity, and also due to children's responses to the food and beverage advertisements shown on television [8-11]. TV food advertisements influence children's food preferences and purchase requests, and consequently their consumption and body weight outcomes [5, 12-14]. In addition, foods marketed to children are often high in saturated fat, sugar and/ or sodium (HFSS) [11, 15]. Links have been established between the marketing of food products with poor nutritional quality and overweight and obesity among children [16-19].

In 2006, the Institute of Medicine Report on Food Marketing to Children and Youth highlighted the need to address the nutritional content of food products advertised to children [5]. Later, a set of seven principles (the Sydney Principles) were developed by World Obesity (formerly the International Obesity Taskforce (IOTF)) in order to guide action and reduce the promotion of unhealthy foods and beverages to children [20]. In 2010 and 2011, both the World Health Organization (WHO) and the Pan American Health Organization (PAHO) supported policies to regulate child-directed advertising of foods with poor nutritional quality, in an effort to protect children from being exposed to these potentially harmful food advertisements [21, 22]. In July 2013 the Ministers of health and representatives of the Member States of the WHO, signed the Vienna Declaration, which included a commitment to take decisive action to reduce the exposure of children to unhealthy food marketing [23]. In May 2013 all Member States adopted the WHO non-communicable disease (NCD) action plan and monitoring framework, which included the reduction of junk food marketing to children as one of the indicators.
Following the recommendations from these international organizations, Mexico introduced a set of regulations in 2015 to limit unhealthy food and beverage advertising to children on screens, both on TV and in movie theaters [24], as part of the 2013 National Strategy for the Prevention and Control of Overweight, Obesity and Diabetes [25]. The nutritional criteria (Additional file 1) for this new policy were created using the European Pledge [26] as a reference. This pledge was developed by the food industry as a commitment to advertise healthier food choices in childdirected media and promote self-regulation instead of legislation [27]. It is designed as a self-regulatory and voluntary initiative where food products advertised have to contain food category-specific components per definition (e.g. dairy products needs to contain at least $50 \%$ dairy), otherwise they should not be advertised. Additionally, depending on the food category, maximum amounts are set for energy, sodium, saturated fats and total sugars. The Mexican regulation allows advertising of food products that do not comply with the nutritional criteria during specific hours, from Monday to Friday between 12:00 am to 2:30 pm and 7:30 pm and 12:00 am, and Saturday and Sunday between $12: 00 \mathrm{am}$ and to 7:00 am and 7:30 pm to $12: 00 \mathrm{am}$. In addition, the nutritional criteria do not apply to those programs targeted to an audience 12 years and older, such as soap operas, sports programing, news, and TV series [24].

Internationally, other nutritional profile models have been developed independently from the food industry to restrict unhealthy food marketing to children, such as a model proposed by the WHO for European countries [28] and one currently used in the United Kingdom [29].

The European nutrient profile model (see Additional file 2) was developed by the WHO Regional Office for Europe, with the objective to use it as a common model to improve the nutritional quality of the foods marketed to children in Members States across Europe [28]. On the other hand, the United Kingdom Profile Model (UKNPM) was developed by the British Heart Foundation Health Promotion Research Group at Oxford University and is currently used in legislation that restricts unhealthy food marketing to children on TV. This model generates a score, which determines whether the food can be advertised to children or not. Two threshold levels are set: one for food products and one for beverages [29].

Assessment of the extent and nature of food marketing to children on TV has previously been performed in Australia, New Zealand, Asia and other countries in Europe, North and South America, but little research has been undertaken in Mexico [15, 30-34]. The current study aims to assess the nutritional quality of food and beverages advertised on Mexican TV, applying 
the Mexican, WHO Europe and UKNPM standards. The present study was conducted before the Mexican regulation came into effect. The hypothesis of the study is that the majority of the foods and beverages advertised on Mexican television promote products high in fat, sugar and sodium.

\section{Methods}

\section{Study design}

We recorded $600 \mathrm{~h}$ of Mexican TV on the four free and public channels with the highest national audience ratings from December 2012 to April 2013 (XHTV Channel 2, XHGC Channel 5, XHIMT Channel 7 and XHDF Channel 13). These channels cover more than $90 \%$ of the Mexican territory [35]. Days were randomly selected over the 5 months, 10 days were recorded per channel from 7 am to $10 \mathrm{pm}$. These recordings included broadcasts to a wide range of audiences and many different types of programs.

As TV programming is different during school and vacation season periods, we included recordings of advertisements for both of those periods in the same year. The official calendar of the Ministry of Public Education of Mexico was used to classify days into school or vacation season [36], and the target audience of the programme was determined according to the Mexican Federal law of Radio and TV: general audience (A classification) or audience of 12 years and older (classification B, B15, C and D) [37]. The types of programs were categorized as sports, soap operas, cartoons, entertainment, movies, or others (i.e.: news, series, contests, musicals, reality shows and health related programs). The categorization was done using a manual used by the Brazilian Institute of Public Opinion and Statistics
(IBOPE, for its acronym in spanish) to measure TV audience [38].

The recordings were captured using 4 digital TV adaptors (WIN TV-HVR / Hybrid Stick 950Q). For coding of the recordings, a manual developed by the Rudd Center for Food Policy \& Obesity was used [18]. Personnel were trained to code the advertisements in a standardized manner. Three research assistants participated in the coding.

\section{Nutritional analysis}

The nutritional content of food and beverage products was obtained from the nutrient declarations of each product; the information was captured by photo in 2015 . When that was not available, nutritional information was obtained from company websites updated in 2015 . Only one product (paleta teleton) was excluded from the nutritional content analysis because its composition could not be obtained from either of these sources. $\mathrm{Nu}$ tritional assessments were based on energy (kilocalories), sugar, fiber, total fat, saturated fat (all in grams), and sodium (milligrams). Data was collected per $100 \mathrm{~g} / \mathrm{ml}$ from all the products advertised.

The nutritional quality was assessed according to 3 different nutrient profile models (see Table 1), each designed to assess the healthiness of food and beverage products advertised on TV in an effort to reduce unhealthy food-marketing targeted to children. The three standards were: (i) The nutritional criteria proposed by the Mexican Ministry of Health for the new regulation (Mexican) [24]; (ii) WHO Regional Office for Europe nutrient profile model (European) [28] and (iii) United Kingdom Nutrient Profiling Model (UKNPM) [29]. All products in each advertisement were assessed separately;

Table 1 Comparison of the nutrient profile models of Mexico, WHO Europe and United Kingdom

\begin{tabular}{|c|c|c|c|}
\hline & Mexican $^{a}$ & WHO Europet & UKNPMキ \\
\hline Based on & Food categories & Food categories & Food or Beverages \\
\hline Categories & 12 categories & 17 categories & - \\
\hline Subcategories & Subcategories & - & - \\
\hline Criteria & $\begin{array}{l}\text { Cut points for nutrition criteria and specified } \\
\text { food groups that are completely in or out for } \\
\text { food marketing. }\end{array}$ & $\begin{array}{l}\text { Cut points for nutrition criteria and specified } \\
\text { food groups that are completely in or out for } \\
\text { food marketing. }\end{array}$ & $\begin{array}{l}\text { Score by points } \\
\text { - "less healthy" } \\
\text { (>4 points for foods and }>1 \\
\text { point for beverages) }\end{array}$ \\
\hline $\begin{array}{l}\text { Nutrients covered by } \\
\text { the model }\end{array}$ & Energy, sodium, saturated fat and total sugar & $\begin{array}{l}\text { Energy, salt, artificial sweeteners, total fat, } \\
\text { saturated fat, total sugar and added sugar }\end{array}$ & $\begin{array}{l}\text { A points } \\
\text { - Energy, saturated fat, total } \\
\text { sugar and sodium } \\
\text { C points } \\
\text { - Fruit, vegetables and nuts; } \\
\text { fiber and protein. }\end{array}$ \\
\hline Measure & Serving size & $100 \mathrm{~g} / \mathrm{ml}$ & $100 \mathrm{~g} / \mathrm{ml}$ \\
\hline Developed by & COFEPRIS based on the European pledge & World Health Organization members & $\begin{array}{l}\text { Academic researchers by } \\
\text { Oxford University }\end{array}$ \\
\hline
\end{tabular}

${ }^{a}$ Mexican Ministry of Health. Nutritional criteria for food and non-Alcoholic beverages advertising in television and cinemas targeted to children. Mexico; 2014 [24]. tWHO Regional Office for Europe [28]. \# Rayner M, Scarborough P, Boxer A, Stockley L. Nutrient profiles: Development of Final Model. British Heart Foundation Health Promotion Research Group, Department of Public Health, University of Oxford; 2005 [29] 
as "less healthy or healthier products" for the three different criteria. We tagged a product as "less healthy" when it did not comply with the specific nutrient criteria, on the other hand products were identified as "healthier products" when they did comply with the specific nutrient criteria. This was done for each nutrient profile model.

The products advertised were grouped into food categories, using the WHO European model as a reference (Additional file 2). In advertisements with more than one product of the same category, the nutritional content was averaged, and when there were products from different categories, the analysis was made for each product.

\section{Statistical analysis}

The nutritional quality of foods advertised was compared between season (school or vacation), days (weekday or weekend), audiences (general population or 12 years and older) and types of programs (sports, soap opera, cartoons, entertainment, movies and others). A MannWhitney $U$ test was used to assess differences in nutritional content and quality of the foods advertised between school and vacation season, week and weekend days and different audiences. Differences by type of program were examined through the Kruskal-Wallis test, applying a Bonferroni correction. All results are shown in medians, and the statistical significance was established for a two-tailed test at $p<0.05$. The analyses were performed using the STATA statistical software package version 12.0 [39].

\section{Results}

During the $600 \mathrm{~h}$ of TV recorded, 2,546 food and nonalcoholic beverage advertisements were broadcast, representing $(20.7 \%)$ of the total advertisements shown. The advertisements featured 275 different food and beverage products, with a mean frequency of 9.2 advertisements per product and an average of 48.96 food and beverage advertisements per day per channel.

During the school season there were 291.3 advertisements of food and beverages per day, 2.6 times more advertisements as compared with the vacation season where 112.7 advertisements per day were observed (Table 2). Considering that there are five weekdays and that each weekend has only two days, there were 2.4 times more advertisements during weekend days than on weekdays; on average there were 258 food and beverages advertisements per day during weekdays compared with 627 on weekend days.

\section{Nutritional content of foods and beverages advertised} The median energy and nutrient content of the foods advertised is shown in Table 3. A food and/or beverage
Table 2 Percentage of advertisements for foods and beverages on Mexican TV, by season, day, audience, type of program and nutritional quality

\begin{tabular}{|c|c|c|}
\hline Variables & Number* & Percent \\
\hline \multicolumn{3}{|l|}{ Season $t$} \\
\hline School & 1754 & 68.9 \\
\hline Average of advertisements per day & 291.3 & \\
\hline Vacation & 792 & 31.1 \\
\hline Average of advertisements per day & 112.7 & \\
\hline \multicolumn{3}{|l|}{ Day } \\
\hline Weekday & 1292 & 50.7 \\
\hline Average of advertisements per day & 258.4 & \\
\hline Weekend & 1254 & 49.2 \\
\hline Average of advertisements per day & 627 & \\
\hline \multicolumn{3}{|l|}{ Audience $\neq$} \\
\hline General & 2217 & 87.0 \\
\hline 12 years and older & 329 & 12.9 \\
\hline \multicolumn{3}{|l|}{ Type of program } \\
\hline Sports & 140 & 5.5 \\
\hline Soap opera & 514 & 20.1 \\
\hline Cartoons & 348 & 13.6 \\
\hline Entertainment & 525 & 20.6 \\
\hline Movies & 725 & 28.4 \\
\hline Other & 294 & 11.5 \\
\hline \multicolumn{3}{|l|}{ Nutritional quality } \\
\hline \multicolumn{3}{|l|}{ Mexican criteria§ } \\
\hline Healthier products & 910 & 35.7 \\
\hline Less healthy products & 1639 & 64.3 \\
\hline \multicolumn{3}{|l|}{ WHO Europe 9} \\
\hline Healthier products & 429 & 16.8 \\
\hline Less healthy products & 2117 & 83.1 \\
\hline \multicolumn{3}{|l|}{ UKNPM ** } \\
\hline Healthier products & 540 & 21.2 \\
\hline Less healthy products & 2006 & 78.7 \\
\hline Total & 2,546 & 100.0 \\
\hline
\end{tabular}

advertised on Mexican TV contained a median of $310 \mathrm{kcal}$ of energy, $12 \mathrm{~g}$ of sugar, $1 \mathrm{~g}$ of fiber, $4 \mathrm{~g}$ of total fat, $2 \mathrm{~g}$ of saturated fat and $164 \mathrm{mg}$ of sodium per $100 \mathrm{~g} / \mathrm{ml}$ of product.

Significant differences were observed in the median energy, sugar, total fat, saturated fat and sodium content of food and beverages advertised by season, day, audience and type of program (See Table 3). Foods and beverages advertised during school season contained significantly higher amounts of energy, sugar, total fat, saturated fat, 
Table 3 Nutritional content of food and beverage advertisements on Mexican TV, by season, day, audience and type of program

\begin{tabular}{|c|c|c|c|c|c|c|c|c|c|c|c|c|c|c|c|c|c|}
\hline \multirow{3}{*}{$\begin{array}{l}\text { Nutritional } \\
\text { content* }\end{array}$} & \multirow[t]{3}{*}{ Total } & \multicolumn{3}{|c|}{ Season $\neq$} & \multicolumn{3}{|l|}{ Daył } & \multicolumn{3}{|c|}{ Audience $\neq$} & \multicolumn{7}{|c|}{ Type of program $\neq$} \\
\hline & & $\begin{array}{l}\text { School } \\
n_{* *} \\
1754\end{array}$ & $\begin{array}{l}\text { Vacation } \\
n_{* *} 792\end{array}$ & $\begin{array}{l}\S p \\
\text { value }\end{array}$ & $\begin{array}{l}\text { Weekday } \\
n * 1292\end{array}$ & $\begin{array}{l}\text { Weekend } \\
n_{* *} 1254\end{array}$ & $\begin{array}{l}\S p \\
\text { value }\end{array}$ & $\begin{array}{l}\text { General } \\
n \\
* 2217\end{array}$ & $\begin{array}{l}12 \text { years } \\
\text { and older } \\
n * 329\end{array}$ & $\begin{array}{l}\S p \\
\text { value }\end{array}$ & $\begin{array}{l}\text { Sports } \\
n * * 140\end{array}$ & $\begin{array}{l}\text { Soap } \\
\text { opera } \\
n * 514\end{array}$ & $\begin{array}{l}\text { Cartoons } \\
n_{* *} 348\end{array}$ & $\begin{array}{l}\text { Entertainment } \\
n_{* *} 525\end{array}$ & $\begin{array}{l}\text { Movies } \\
n_{* *} 725\end{array}$ & $\begin{array}{l}\text { Others } \\
n_{* * 294}\end{array}$ & $\begin{array}{l}p \\
\text { value }\end{array}$ \\
\hline & & $\mathrm{M}+$ & $\mathrm{M}+$ & & $\underline{\mathrm{M}}+$ & $\mathrm{M}+$ & & $\mathrm{M}+$ & $\mathrm{M}+$ & & $\underline{\mathrm{M}}+$ & $\mathrm{M} \dagger$ & $\mathrm{M}+$ & $\mathrm{M}+$ & $\mathrm{M}+$ & $\mathrm{M}+$ & \\
\hline Energy (kcal) & 310.0 & 318.0 & 252.5 & $<0.001$ & 247.2 & 347.5 & $<0.001$ & 310.0 & 263.6 & 0.02 & $\begin{array}{l}270.0 \\
b, c, d, e, f\end{array}$ & $\begin{array}{l}224.0 \\
a, c, d, d, f, f\end{array}$ & $\begin{array}{l}367.0 \\
a, b, d, d, f, f\end{array}$ & $273.0^{a, b, c, e, f}$ & $\begin{array}{l}331.0 \\
a, b, c, c, d, f\end{array}$ & $\begin{array}{l}305.5 \\
a, b, c, d, e\end{array}$ & $<0.001$ \\
\hline Sugar (g) & 12.0 & 12.4 & 10.0 & $<0.001$ & 12.0 & 12.0 & 0.09 & 12.3 & 10.0 & $<0.001$ & $4.5^{b, c, d, e, f}$ & $10.0^{a, c, d, e, f}$ & $30.0^{a, b, d, e, f}$ & $11.0^{a, b, c, e, f}$ & $11.0^{a, b, c, d, f}$ & $12.0^{\mathrm{a}, \mathrm{b}, \mathrm{c}, \mathrm{d}, \mathrm{e}}$ & $<0.001$ \\
\hline Fiber (g) & 1.0 & 1.0 & 1.0 & 0.07 & 0.0 & 2.0 & $<0.001$ & 1.0 & 0.0 & 0.07 & $1.7^{b, c, d, d, f f}$ & $0.0^{\mathrm{a}, \mathrm{c}, \mathrm{d}, \mathrm{e}}$ & $1.5^{\mathrm{a}, \mathrm{b}, \mathrm{d}, \mathrm{e}, \mathrm{f}}$ & $1.3^{a, b, c, e, f}$ & $1.8^{\mathrm{a}, \mathrm{b}, \mathrm{c}, \mathrm{d}, \mathrm{f}}$ & $0.0^{\mathrm{a}, \mathrm{c}, \mathrm{d}, \mathrm{e}}$ & $<0.001$ \\
\hline Total fat (g) & 4.0 & 6.0 & 2.0 & $<0.001$ & 3.0 & 8.2 & $<0.001$ & 4.0 & 6.0 & 0.57 & $9.5^{b, c, d, f}$ & $2.6^{a, c, d, d, f}$ & $3.0^{a, b, d, e, f}$ & $3.0^{\mathrm{a}, \mathrm{b}, \mathrm{c}, \mathrm{e}}$ & $9.0^{a, b, c, d, f}$ & $4.0^{\mathrm{a}, \mathrm{b}, \mathrm{c}, \mathrm{e}}$ & $<0.001$ \\
\hline $\begin{array}{l}\text { Saturated fat } \\
\text { (g) }\end{array}$ & 2.0 & 2.0 & 1.0 & $<0.001$ & 1.0 & 4.0 & $<0.001$ & 2.0 & 2.0 & 0.17 & $2.2^{b, c, d, e, f}$ & $1.0^{a, c, d, d, e, f}$ & $2.0^{a, b, e}$ & $1.0^{\mathrm{a}, \mathrm{b}, \mathrm{e}}$ & $5.0^{b, c, d, f, f}$ & $2.0^{\mathrm{a}, \mathrm{b}, \mathrm{e}}$ & $<0.001$ \\
\hline Sodium (mg) & 164.0 & 240.8 & 96.0 & $<0.001$ & 100.0 & 244.0 & $<0.001$ & 178.0 & 132.0 & 0.01 & $412^{b, c, d, e, f}$ & $\begin{array}{l}100.0 \\
a, c, d, d, f, f\end{array}$ & $125.0^{a, b, e}$ & $125.0^{a, b, e}$ & $\begin{array}{l}240.8 \\
a, b, c, d, f, f\end{array}$ & $163.0^{a, b, e}$ & $<0.001$ \\
\hline
\end{tabular}

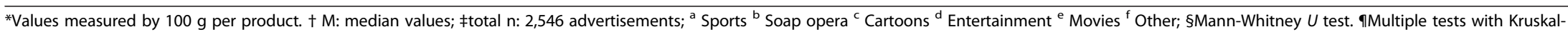
Wallis adjusted with Bonferroni-type; ** $n$ : number of advertisements 
and sodium compared to those advertised during the vacation season. Similar results were observed for weekend days compared to weekdays with the exception of sugar, where there were no statistically significant differences. Products advertised during programs targeting a general audience contained more energy, sugar and sodium compared to the programs targeted at an audience 12 years and older. Food products advertised during cartoon programs had the highest energy and sugar content, while those advertised during sports programs had the highest fat and sodium content compared to the other type of programs.

\section{Nutritional quality of foods and beverages advertised}

More than $60.0 \%$ of the foods and beverages advertised on Mexican TV did not meet any of the three nutrient profile model quality standards, as shown in Table 2 . $64.3 \%$ of the products advertised did not comply with the Mexican nutritional standards, as compared with $83.1 \%$ and $78.7 \%$ with WHO Europe and UKNPM standards, respectively.

Figure 1 demonstrates the differences found in the evaluation of the nutritional quality of food and beverages advertised on Mexican TV by season, day and type of program. The percentage of foods advertised that depicted healthier products that met the Mexican, WHO Europe and UKNPM standards was higher in vacation than school season, $(38.2 \%$ vs. $34.6 \% p=0.07,20.5 \%$ vs. $15.1 \% p=<0.01$ and $29.8 \%$ vs. $17.2 \% p=<0.01$, respectively), and higher during weekdays than on weekend days:
( $40.3 \%$ vs. $31.0 \% p=<0.01,19.2 \%$ vs. $14.2 \% p=<0.01$, and $25.4 \%$ vs. $16.8 \% p=<0.01$, respectively).

During cartoon programming, only $33.9 \%, 8.6 \%$, and $17.2 \%$ of the foods advertised complied with the Mexican, WHO Europe and UKNPM standards. Foods advertised in these types of programs had a lower nutritional quality in the three different criteria, as compared with other types of programming $(p=<0.05)$.

Food and beverage categories most frequently advertised Considering that some of the advertisements depicted more than one product, there were 17 different food categories, which appeared 2,785 times in 2,546-recorded advertisements. The majority of advertisements were for beverages (24.6\%), followed by chocolate and confectionery (19.7\%), sweet biscuits and pastries $(12.0 \%)$, savory snacks $(9.3 \%)$, breakfast cereals $(7.1 \%)$, ready-made food $(6.4 \%)$ and dairy products $(6.0 \%)$. The food categories with the lowest percentage of advertisements were: fruit, vegetables and legumes, and meat, poultry and fish. None of the food and beverage TV advertisements were for fresh fruit, vegetables, or legumes. Additionally, the results demonstrate that Mexican standards allow a higher proportion of cereals (75.8\%), yogurts (52.7\%), and cakes, biscuits and pastries (38.4 \%) to be advertised, compared to European and UKNP models. The results are shown in Table 4.

Categories of products advertised the most, did not differ significantly by season, day or audience, as

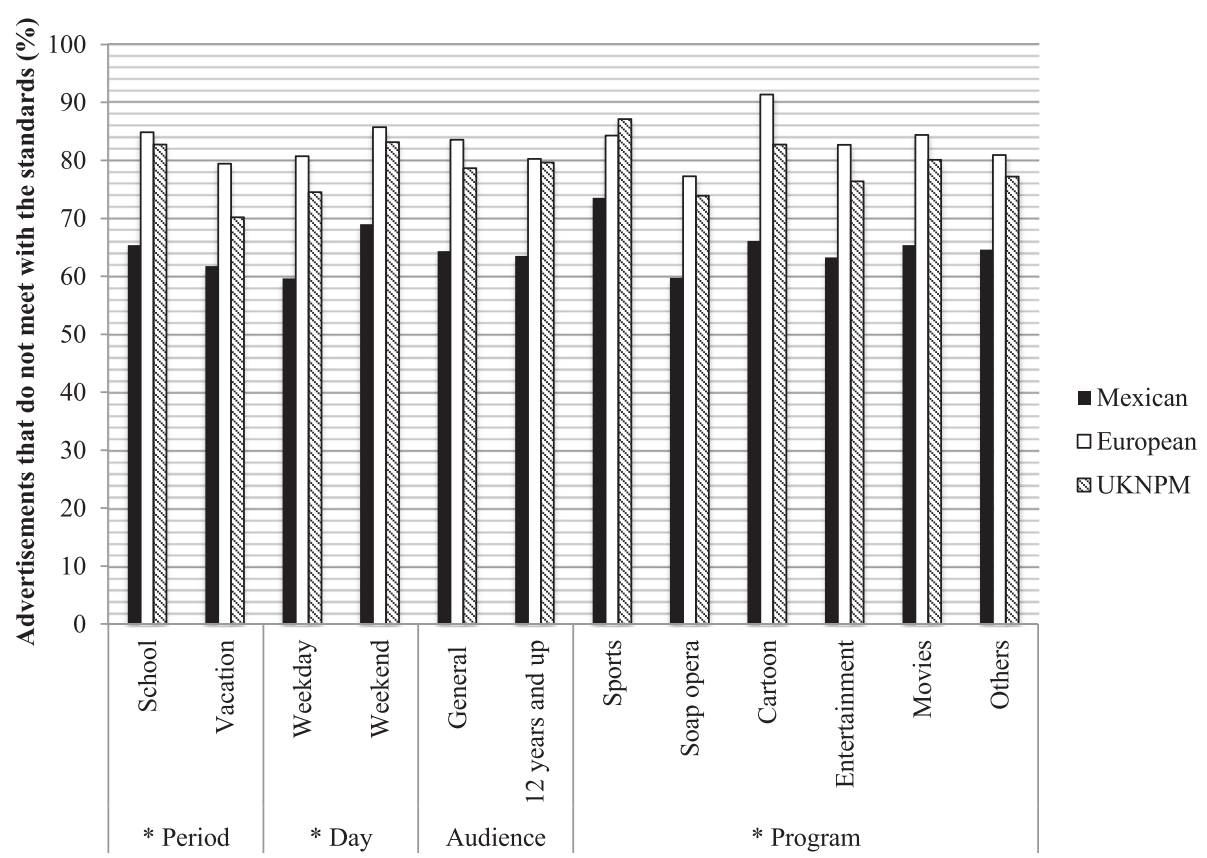

Fig. 1 Nutritional quality of food and beverage advertisements on Mexican TV, according to three nutrient profile standards 
Table 4 Percentage of food and beverage advertisements on Mexican TV, that do not comply with the nutrient profile standards, by food category

\begin{tabular}{|c|c|c|c|c|c|c|c|c|}
\hline \multirow[t]{3}{*}{ Categories } & \multirow{2}{*}{\multicolumn{2}{|c|}{ Total }} & \multicolumn{6}{|c|}{ "Less healthy" } \\
\hline & & & \multicolumn{2}{|c|}{ Mexican standards } & \multicolumn{2}{|c|}{ WHO* Europe standards } & \multicolumn{2}{|c|}{ UKNPM* standard } \\
\hline & $\overline{n^{\dagger}}$ & $\%$ & $\overline{n^{\dagger}}$ & $\%$ & $\overline{n^{\dagger}}$ & $\%$ & $\overline{n^{\dagger}}$ & $\%$ \\
\hline Beverages & 686 & 24.6 & 439 & 63.9 & 514 & 74.9 & 447 & 65.1 \\
\hline Chocolate and sugar confectionery & 549 & 19.7 & 493 & 89.8 & 549 & 100 & 464 & 84.5 \\
\hline Cakes, biscuits and pastries & 336 & 12 & 207 & 61.6 & 336 & 100 & 336 & 100 \\
\hline Savory snacks & 261 & 9.3 & 247 & 94.6 & 261 & 100 & 261 & 100 \\
\hline Breakfast cereal & 198 & 7.1 & 48 & 24.2 & 197 & 99.4 & 198 & 100 \\
\hline Ready-made food and dishes & 179 & 6.4 & 125 & 69.8 & 125 & 69.8 & 100 & 55.8 \\
\hline Yoghurts, milk and similar foods (dairy) & 167 & 6 & 79 & 47.3 & 156 & 93.4 & 165 & 98.8 \\
\hline Sauces, dips and dressings & 89 & 3.2 & 80 & 89.8 & 68 & 76.4 & 49 & 55 \\
\hline Bread, bread products and crisp breads & 85 & 3 & 52 & 61.1 & 23 & 27 & 68 & 80 \\
\hline Fresh or dried pasta, rice and grains & 82 & 2.9 & 12 & 14.6 & 0 & 0 & 28 & 34.1 \\
\hline Edible ices & 57 & 2 & 22 & 38.6 & 57 & 100 & 40 & 70.1 \\
\hline Butter and other fats and oils & 40 & 1.4 & 15 & 37.5 & 15 & 37.5 & 40 & 100 \\
\hline Cheese & 30 & 1 & 30 & 100 & 29 & 96.6 & 30 & 100 \\
\hline Processed meat, poultry, fish and similar & 21 & 0.7 & 9 & 42.8 & 9 & 42.8 & 16 & 76.1 \\
\hline Processed fruit, vegetables and legumes & 3 & 0.1 & 3 & 100 & 3 & 100 & 3 & 100 \\
\hline Meat, poultry, fish and similar & 2 & 0 & 0 & 0 & 0 & 0 & 0 & 0 \\
\hline Fresh and frozen fruit, vegetables and legumes & 0 & 0 & 0 & 0 & 0 & 0 & 0 & 0 \\
\hline Total & 2,785 & 100 & 1861 & 66.8 & 2342 & 84 & 2245 & 80.6 \\
\hline
\end{tabular}

*WHO "World Health Organization"; UKNPM "United Kingdom Nutrient Profile Model"; Categories according to the WHO Regional Office for Europe nutrient profile model [28], shown in supplementary material 2.†n: number of advertisements

shown in Fig. 2. Beverages were the most popular category, although they were shown significantly more often during vacation season $(28.9 \%, n=249)$ compared to school season $(21.9 \%, n=437)$; on weekdays (25.4 \%, $n=361)$ compared to weekend days $(22.7 \%$, $n=325)$; and for an audience of 12 years and up $(30.4 \%, n=111)$ compared to a general audience $(23.1 \%, n=575)$. Based on type of program shown in Fig. 3, only sports programming had the majority of advertisements for the savory snacks category $(28.7 \%$, $n=42$ ). In cartoons the majority of advertisements were for the chocolate and confectionery category (39.4\%, $n=152)$. For other types of programming (soap opera, entertainment, movies and others) beverages remained the most popular.

Table 4 shows the percentage of "less healthy" products depicted in advertisements, namely those that do not comply with the nutrient profile standards of Mexico, WHO Europe and UKNPM by food category. Apart from fresh produce, the percentage of foods advertised that complied with the standards was higher within the food category of fresh or dried pasta, rice and grain products. Within this category, $85.3 \%$ of products complied with the Mexican standards, $100 \%$ with the European, and $65.8 \%$ with the UKNPM. In addition, the three different standards considered all the meat, poultry, fish and similar products shown in Mexican TV as healthier products.

\section{Discussion}

This study is the first one to examine the nutritional quality of food and beverages advertised on Mexican TV, analyzed according to the Mexican, WHO Europe and UK nutrient profile models. More than $60 \%$ of the foods and beverages advertised on Mexican TV did not comply with any of the nutritional quality standards, and thus should not have been marketed to children. According to the three models, the food products advertised on Mexican TV had a poor nutrient profile, especially during cartoons and sports programming.

Our findings are similar to what previous studies have found in other countries. Diverse reports have found that the nutritional content of products advertised on $\mathrm{TV}$ is more frequently high in HFSS and most of them are targeted during children's programming [18, 40, 41]. These findings are also demonstrated in the current study; advertisements with the highest amount of sugar 


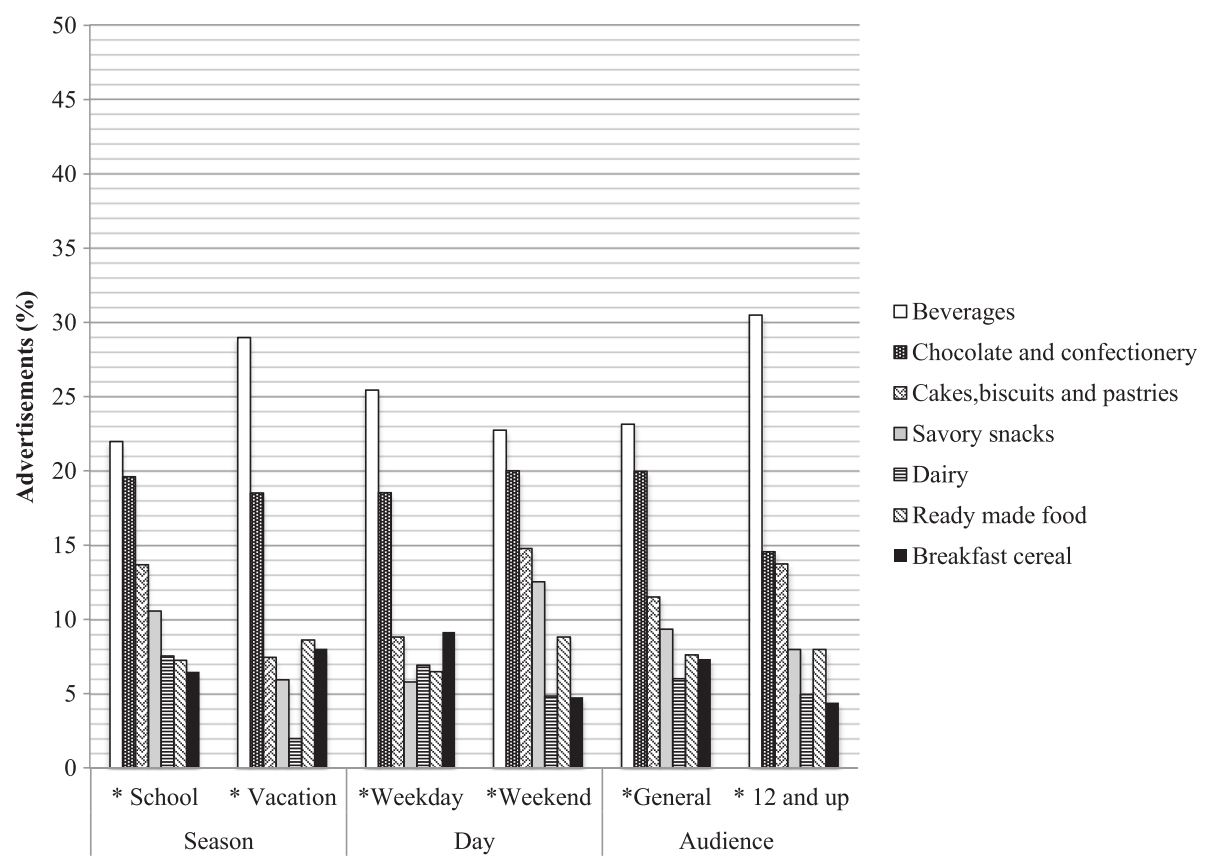

Fig. 2 Comparison of the most shown categories advertisements on Mexican TV, by season, day and audience

and energy were broadcast in cartoons, program classified appropriate for children. This can be explained by the fact that $39.4 \%$ of the advertisements shown during cartoons fell into the chocolate and sugar confectionery category. Our results for fat and sodium differed from other studies as we showed that the advertisements for products with the highest amount of fat and sodium were shown during sports programming. This can be explained by the fact that $28.7 \%$ of the advertisements shown during this type of programming were for snack foods.

On average, beverages, candy, snacks, breakfast cereals, dairy, and prepared foods (including fast food) accounted for the most advertisements shown on TV. International studies also suggest that these categories are the most frequently advertised on TV [16, 30, 41, 42]. It is important

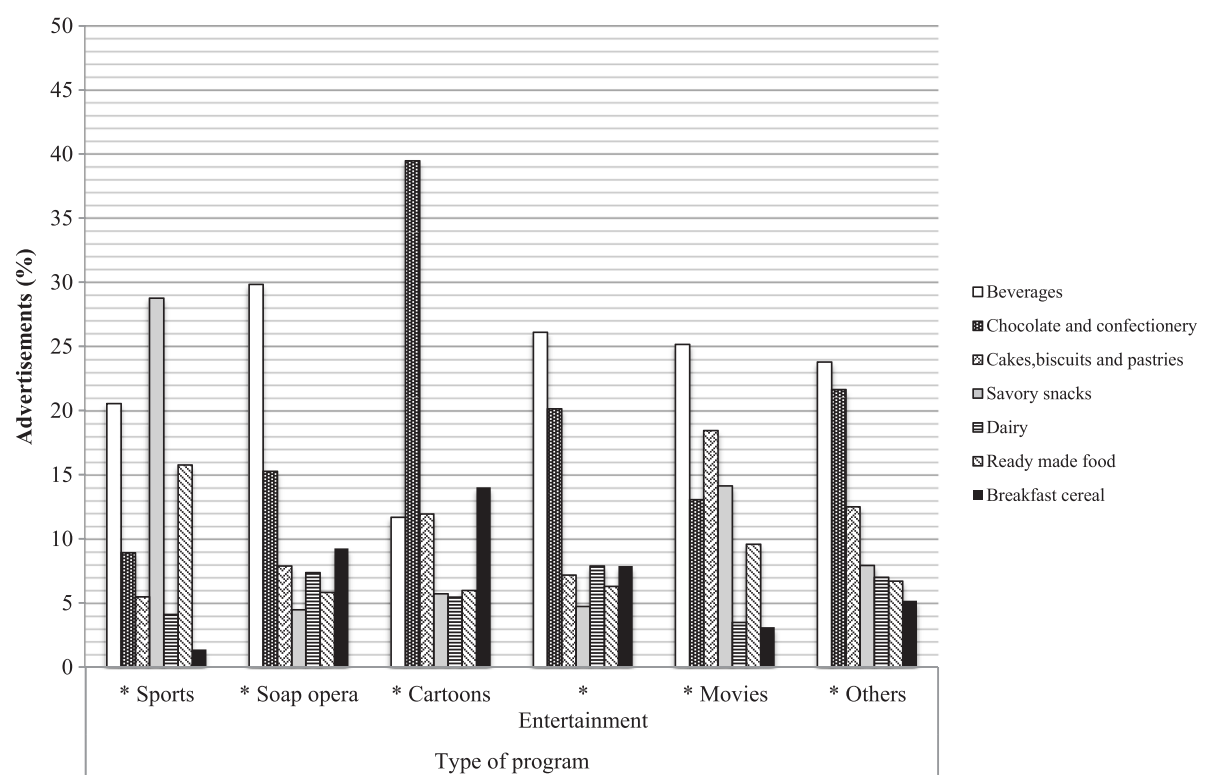

Fig. 3 Comparison of the most shown categories of food and beverage advertisements on Mexican TV, by type of program 
to note that the products in these categories often have considerable amounts of energy, sugar, fat and sodium $[34,42]$. In contrast, in the present study, the most nutritious categories (fresh and frozen fruit, vegetables and legumes, meat, poultry, fish and similar) represented less than $1 \%$ of advertisements, and were significantly less likely to appear in advertisements compared to other categories.

Findings about food and beverage advertisement shown more often during school season could not be explained with scientific evidence. Nevertheless, during this period, people are in a routine and allocate specific time to watch TV; we can assume that food marketing is higher compared to those days where people abandon their routine, such as vacation season.

Results of the evaluation of the nutritional quality based on UKNPM were consistent with other recent study results. In Spain in 2012, $61.5 \%$ of the products advertised were less healthy [34], while in New Zealand in 2007 the proportion was $66.3 \%$ [43]. In Canada and the UK in 2006, the proportion of less healthy food advertised on TV was $65.7 \%$ and $54.5 \%$, respectively [44]. In the present study, it was observed that in Mexico $78.79 \%$ of the advertisements contained products that cannot be advertised according to this standard. Brinsden and Lobstein in 2013 reported that in the United States $63 \%$ of the products advertised were less healthy products [45]. The researchers also compared different nutrient profile schemes, and found that, though the proportion of products that were allowed to be advertised varies according to each standard, it was still the minority of advertised products that were of high enough nutrition quality to be advertised. These results were similar to the current study.

Studies have found links between TV food advertising and consumption. They consistently demonstrate that food and beverage advertisements on TV influence children's food preferences, purchasing requests and eating behaviors, which has harmful effects on young people's diets, and can cause obesity and related diseases $[5,13$, $46,47]$. Further evidence demonstrates that it is extraordinarily difficult to counteract the influence of food marketing, even for adults, especially when it promotes HFSS products [48].

There is little documentation on the effect of regulation on TV advertising $[49,50]$, but modeling projections indicate that regulation would be a cost-effective strategy $[51,52]$. Mexico has introduced a regulation regarding TV advertising of food and beverages to children. This study shows that the foods and beverages advertised on Mexican TV do not meet the regulations. Moreover, the poor nutritional quality of the majority of food and beverage products in advertisements on TV has left Mexican children exposed to substantial amounts of unhealthy food advertising, which likely contributes to obesity. While these regulations are a good first step, Mexico needs stricter regulations with nutrient profile standards similar to WHO and UK. The Mexican standards have the least strict nutrition criteria among the three, leaving products with a considerably high amount of energy, sugar and fat being advertised to children; especially in food categories, such as cereals, yogurts and cakes. These results suggest that, if the Mexican criteria reinforce the cut off points for sugar, it would improve the quality of products advertised on television. Additionally, this strategy needs to be supported by complementary actions such as, reformulation of foods and beverages, prepackaging portion sizes, raising awareness and education.

Of course, given the multiple channels of marketing such as school marketing, movies, social media, and supermarkets; TV is just one of the many sources of food and beverage advertisements that can influence children's purchase behavior. However, TV viewing has been firmly linked to childhood obesity, through the effect of the power of advertisements for HFSS foods on TV. Furthermore, there is evidence that documents little progress in reducing unhealthy food advertising to children under age $12[53,54]$.

This is the first study that provides information on the nutritional content of Mexican TV with national data before the regulation started in 2015 . The results can be useful in evaluating the changes in food and beverage advertisements in Mexican TV before and after the regulation started.

Future work could investigate the exposure of the Mexican population to the food and beverages advertised, and the power of the advertisements (promotional characters, premium offers) and evaluate the effect that they may have had on Mexican population. Additionally, further studies should also address whether the Mexican regulation is working and examine the difference between Mexican children's actual exposure to unhealthy food advertising under the current law and what it would have been with other standards (WHO or UK) during the same time.

Our findings are subject to limitations. First, the present study does not evaluate product placements within the TV shows, although this data covered the majority of the products advertised on Mexican TV. Channels were selected based on general data instead of audience data specifically for children, so there is no data on children's peak and non peak viewing times to compare. Furthermore, the nutritional composition data for products was collected more recently than the advertisement recordings, which may have created small discrepancies among the data collected from nutritional content presented in advertisements. The strengths of the present study are its large sample sizes, $600 \mathrm{~h}$ 
recorded from channels with very high rating at national level. Thus, it is unlikely that a different selection of TV channels would change the findings, because both the number and type of advertisements are similar on the different channels. Another strength of this research is its objective approach, which uses different quality standards, and provides evidence and results that are therefore comparable with others studies from foreign countries.

\section{Conclusions}

In summary, this study is the first one to examine the nutritional quality of foods and beverage products advertised on Mexican TV. We conclude that the majority of food and beverage advertisements aired do not comply with any nutrition quality standard and were considered to promote less healthy products, especially during cartoons and sports programming. We suggest a need for constructive engagement with the government to improve and strengthen the regulation of food and beverages aimed at children. Progress in policy development may be difficult, specifically classifying products for which marketing should be restricted. Although nutrient profile models could help, there are international recommendations that consider it unsuitable to advertise any kind of industrialized foods to children [22]. However, the use of the UKNPM or European standards to reinforce the Mexican nutritional standard, the one with the most lax criteria should be considered, especially to improve sugar cut off points. TV is one of the many screen-based advertising vehicles that contribute to children's exposure to HFSS food and beverages. Thus, regulatory strategies on the topic should be supported by other public health actions to promote healthy environments.

\section{Additional files}

Additional file 1: Mexican nutrition criteria for food and beverage advertised on TV and cinemas [24]. (DOCX $23 \mathrm{~kb}$ )

Additional file 2: WHO Europe Nutrient Profile Model [28] (DOCX $19 \mathrm{~kb}$ )

\section{Abbreviations \\ ENSANUT, National Health and Nutrition Survey; HFSS, high in saturated fat, sugar and/or sodium; IOTF, International Obesity Taskforce; NCD, Non- communicable disease; PHAO, Pan American Health Organization; TV, television; UKNPM, United Kingdom Profile Model; WHO, World Health Organization}

\section{Acknowledgements}

The authors acknowledge the academic support given by National School of Public Health of Mexico and would like to thank Liliana Bahena Espina, BSc, MEd from the National Institute of Public Health Mexico for her collaboration and insight of the paper and databases.

\section{Funding}

The study financial support was provided by Bloomberg Philanthropies and the National Council of Science and Technology of Mexico (CONACYT). Project number: 1305.

\section{Author's contributions}

RGPS took part in bibliographical research, entered and analyzed the data, interpretation of results, and editing every part of the manuscript. TMML wrote the research protocol, suggested the research idea, in charge of the data acquisition and helped in the literature search for the background and editing the document. MFE have been involved in the analysis and interpretation of data. HLJ outlined the variables to be considered for the study, took part in the interpretation of the results and checking the manuscript. VS contributed in drafting and revising critically the manuscript and its intellectual content. DRJ contribute with de data acquisition, edited and reviewed the document. BS responsible of the data acquisition, contributed to the writing of the manuscript. All authors read and approved the final manuscript.

\section{Author's information}

Not applicable.

\section{Competing interests}

The authors declare that they have no competing interest.

\section{Author details}

${ }^{1}$ Centro de Investigación en Nutrición y Salud, Instituto Nacional de Salud Pública, Av. Universidad No. 655, CP 62100 Cuernavaca, Morelos, México. ${ }^{2}$ Rudd Center for Food Policy \& Obesity, One Constitution Plaza, Kinsley St, Hartford, CT 06103, USA. ${ }^{3}$ School of Population Health, The University of Auckland, Private Bag 92019, Auckland 1142, New Zealand.

Received: 12 November 2015 Accepted: 13 July 2016

Published online: 05 August 2016

\section{References}

1. Lobstein T, Jackson-Leach R, Moodie ML, Hall KD, Gortmaker SL, Swinburn $B A$, et al. Child and adolescent obesity: part of a bigger picture. Lancet Lond Engl. 2015;385(9986):2510-20.

2. Cui W. Poor nutrition is increasing rates of overweight in developing countries. BMJ. 2011;342:d1787.

3. Gutiérrez JP,Rivera-Dommarco J,Shamah-Levy T,Villalpando-Hernández S,Franco A,Cuevas-Nasu L,et al.Encuesta Nacional de Salud y Nutrición 2012. Salúd Pública(MX).2012.

4. Lawlor DA, Benfield L, Logue J, Tilling K, Howe LD, Fraser A, et al. Association between general and central adiposity in childhood,and change in these,with cardiovascular risk factors in adolescence: prospective cohort study. BMJ. 2010;341:c6224.

5. McGinnis JM, Gootman JA, Kraak VI. Food Marketing to Children and Youth: Threat or Opportunity? Committee on Food Marketing and the Diets of Children and Youth.[Internet]. Institute of Medicine.The National Academies Press; 2006. 536 p. Available from: http://www.nap.edu/catalog/11514.html.

6. Popkin BM, Adair LS, Ng SWNOWAND. THEN:The Global Nutrition Transition: The Pandemic of Obesity in Developing Countries. Nutr Rev. 2012;70(1):3-21.

7. Guran T, Bereket A. International epidemic of childhood obesity and television viewing. Minerva Pediatr. 2011;63(6):483-90.

8. Hancox RJ, Milne BJ, Poulton R. Association between child and adolescent television viewing and adult health:a longitudinal birth cohort study. Lancet. 2004;364(9430):257-62.

9. Reilly JJ, Wilson D. Childhood obesity. BMJ. 2006;333(7580):1207-10.

10. Hastings $G$, Cairns $G$. The extent,nature and effects of food promotion to children:A review of the evidence to 2008. Geneve: World Health Organization; 2009.

11. Zimmerman FJ, Bell JF. Associations of television content type and obesity in children. Am J Public Health. 2010;100(2):334-40.

12. Sadeghirad B, Duhaney T, Motaghipisheh S, Campbell NRC, Johnston BC. Influence of unhealthy food and beverage marketing on children's dietary intake and preference: a systematic review and meta-analysis of randomized trials. Obes Rev Off J Int Assoc Study Obes. 2016 Jul 18.

13. Roberto CA, Baik J, Harris JL, Brownell KD. Influence of licensed characters on children's taste and snack preferences. Pediatrics. 2010;126(1):88-93. 
14. Boyland EJ, Halford JCG. Television advertising and branding. Effects on eating behaviour and food preferences in children. Appetite. 2013;62:236-41.

15. Harris JL, Schwartz MB, Brownell KD. Marketing foods to children and adolescents:licensed characters and other promotions on packaged foods in the supermarket. Public Health Nutr. 2010;13(3):409-17.

16. Powell LM, Schermbeck RM, Szczypka G, Chaloupka FJ, Braunschweig CL. Trends in the Nutritional Content of TV Food Advertisements Seen by Children in the US:Analyses by Age, Food Categories and Companies. Arch Pediatr Adolesc Med. 2011;165(12):1078-86.

17. Kraak VI, Story M, Wartella EA, Ginter J. Industry progress to market a healthful diet to American children and adolescents. Am J Prev Med. 2011;41(3):322-33. quiz A4.

18. Harris JL, Schwartz MB, Brownell D, et al. Cereal FACTS. Limited progress in the nutrition quality and marketing of children's cereals. Rudd Center for Policy \& Obesity; Yale University: 2012. Available from: http://www. cerealfacts.org/media/cereal_facts_report_2012_7.12.pdf.

19. Goris JM, Petersen S, Stamatakis E, Veerman JL. Television food advertising and the prevalence of childhood overweight and obesity: a multicountry comparison. Public Health Nutr. 2010;13(7):1003-12.

20. Swinburn B, Sacks G, Lobstein T, Rigby N, Baur LA, Brownell KD, et al. The "Sydney Principles" for reducing the commercial promotion of foods and beverages to children. Public Health Nutr. 2008;11(9):881-6.

21. World Health Organization. Recommendations on the Marketing of Food and non-Alcoholic Beverages to Childrens. Geneva: WHO; 2010.

22. Pan American Health Organization. Recommendations from a Pan American Health Organization Expert Consultation on the Marketing of Food and NonAlcoholic Beverages to Children in the Americas. Washington: PHAO; 2011.

23. WHO Regional Office for Europe.Vienna Declaration on Nutrition and Noncommunicable Diseases in the Context of Health 2020.[Internet]. Copenhaguen; 2013. Available from: http://www.euro.who.int/en/mediacentre/events/events/2013/07/vienna-conference-on-nutrition-andnoncommunicable-diseases/documentation/vienna-declaration-on-nutritionand-noncommunicable-diseases-in-the-context-of-health-2020.

24. Diario Oficial de la Federación. LINEAMIENTOS por los que se dan a conocer los criterios nutrimentales y de publicidad que deberán observar los anunciantes de alimentos y bebidas no alcohólicas para publicitar sus productos en televisión abierta y restringida, así como en salas de exhibicióncinematográfica, conforme a lo dispuesto en los artículos 22 Bis, 79, fracción X y 86, fracción VI, del Reglamento de la Ley General de Salud en Materia de Publicidad. [Internet]. México; 2014. Avialiable from: http:// www.dof.gob.mx/nota_detalle.php?codigo=5340694\&fecha=15/04/2014.

25. Secretaría de Salud. Estrategia Nacional para la Prevención y el Control del Sobrepeso, la Obesidad y la Diabetes. Mexico: IEPSA, Entidad Paraestatal del Gobierno Federal. 2013.

26. EU Pledge Nutrition White Paper. EU Pledge Nutrition Criteria White Paper[Internet]. 2015. Available from:http://www.eu-pledge.eu/sites/eupledge.eu/files/releases/EU_Pledge_Nutrition_White_Paper_Nov_2012.pdf.

27. Jensen JD, Ronit K. The EU pledge for responsible marketing of food and beverages to children: implementation in food companies. Eur J Clin Nutr. 2015;69(8):896-901.

28. WHO Regional Office for Europe. WHO Regional Office for Europe nutrient profile model [Internet]. 2015. Available from: http://www.euro.who.int/_data/ assets/pdf_file/0005/270716/Nutrient-Profile-Model_Version-for-Web.pdf.

29. Rayner M, Scarborough P, Boxer A, Stockley L. Nutrient profiles: Development of final model. London: Food Standards Agency, 2005. Available from: http://www.food.gov.uk/multimedia/pdfs/nutprofr.pdf.

30. Harrison K, Marske AL. Nutritional content of foods advertised during the television programs children watch most. Am J Public Health. 2005;95(9):1568-74.

31. Hawkes C, Harris JL. An analysis of the content of food industry pledges on marketing to children. Public Health Nutrition. 2011;14:1403-14.

32. Kelly B, Hattersley L, King L, Flood V. Persuasive food marketing to children: use of cartoons and competitions in Australian commercial television advertisements. Health Promot Int. 2008;23(4):337-44.

33. Pérez-Salgado D, Rivera-Márquez JA, Ortiz-Hernández L. Publicidad de alimentos en la programación de la televisión mexicana: ¿los niños están más expuestos? Salud Pública México. 2010;52(2):119-26.

34. Romero-Fernandez MM, Royo-Bordonada MA, Rodriguez-Artalejo F. Evaluation of food and beverage television advertising during children's viewing time in Spain using the UK nutrient profile model. Public Health Nutr. 2013;16(7):1314-20.
35. Telecom-CIDE. Condiciones del Mercado de Televisión Abierta en México, del Estudio Sobre el Mercado de Servicios de Televisión Abierta en México. [Internet]. 2011.Available from: http://www.observatel.org/es/uploads/1/ Estudio_y_anexo.Alcance.pdf.

36. Ministry of Public Education of Mexico. Official Schoolar Calendar 20132014.[Internet].2013. Available from: http://www.educacionespecial.sep.gob. $\mathrm{mx} / \mathrm{pdf} /$ calendario/calendario13-14.pdf.

37. Chamber of Mexican Deputies. Regulation of the Federal Law of Radio and Television.[Internet]. 2002. Available from:http://www.diputados.gob.mx/ LeyesBiblio/regley/Reg_LFRT_MCPCTRT.pdf.

38. Jara EJR. ¿Cómo la ves?La televisión mexicana y su público. México: IBOPE $A G B ; 2007$. p. 215

39. Hills M, De Stavola BL. Short Introduction to Stata for Biostatistics. London: Timberlake Consultants; 2012. p. 181.

40. Powell LM, Schermbeck RM, Chaloupka FJ. Nutritional Content of Food and Beverage Products in Television Advertisements Seen on Children's Programming. Child Obes. 2013;9(6):524-31.

41. Keller SK, Schulz PJ. Distorted food pyramid in kids programmes:a content analysis of television advertising watched in Switzerland. Eur J Public Health. 2011;21(3):300-5.

42. Mchiza ZJ, Temple NJ, Steyn NP, Abrahams Z, Clayford M. Content analysis of television food advertisements aimed at adults and children in South Africa. Public Health Nutr. 2013;16(12):2213-20.

43. Jenkin G, Wilson N, Hermanson N. Identifying "unhealthy" food advertising on television: a case study applying the UK Nutrient Profile model. Public Health Nutr. 2009;12(5):614-23.

44. Adams J, Hennessy-Priest K, Ingimarsdottir S, Sheeshka J, Ostbye T, White M. Food advertising during children's television in Canada and the UK. Arch Dis Child. 2009;94(9):658-62.

45. Brinsden H, Lobstein T. Comparison of nutrient profiling schemes for restricting the marketing of food and drink to children. Pediatr Obes. 2013;8(4):325-37.

46. Andreyeva T, Kelly IR, Harris JL. Exposure to food advertising on television: Associations with children's fast food and soft drink consumption and obesity. Econ Hum Biol. 2011;9(3):221-33.

47. Boyland E, Nolan S, Kelly B, Tudur-Smith C, Jones A, Halford JC, et al. Advertising as a cue to consume: a systematic review and meta-analysis of the effects of acute exposure to unhealthy food and nonalcoholic beverage advertising on intake in children and adults. Am J Clin Nutr. 2016;103(2):519-33.

48. Halford JCG, Boyland EJ, Hughes G, Oliveira LP, Dovey TM. Beyond-brand effect of television(TV) food advertisements/commercials on caloric intake and food choice of 5-7-year-old children. Appetite. 2007;49(1):263-7.

49. Dhar T, Baylis K. Fast food consumption and the ban on advertising targeting children: the Quebec experience. JMark Res. 2011;48:799-813.

50. Kim S, Lee Y, Yoon J, Chung SJ, Lee SK, Kim H. Restriction of television food advertising in South Korea: impact on advertising of food companies. Health PromotInt. 2013;28:17-25.

51. Kelly B, King L, Bauman A, Smith BJ, Flood V. The effects of different regulation systems on television food advertising to children. Aust NZ J Publ Health. 2007:31:340-3.

52. Cecchini M, Sassi F, Lauer JA, Lee YY, Guajardo-Barron V, Chisholm D. Tackling of unhealthy diets, physical inactivity, and obesity: health effects and cost-effectiveness. Lancet. 2010;376:1775-84.

53. Kunkel DL, Castonguay JS, Filer CR. Evaluating Industry Self-Regulation of Food Marketing to Children. Am J Prev Med. 2015;49(2):181-7.

54. Powell LM, Harris JL, Fox T. Food marketing expenditures aimed at youth: putting the numbers in context. Am J Prev Med. 2013;45(4):453-61. 